\title{
PRIORITY OF FISHING PORT EXPANSION IN NORTHERN COAST OF CENTRAL JAVA BASED ON THE SUPPORTING POWER POTENCY
}

\author{
Ernani Lubis and Anwar Bey Pane \\ Lecturer in Faculty of Fisheries and Marine Science, Bogor Agricultural University, Bogor \\ Received February 1-2010; Received in revised form May 17-2010; Accepted June 18-2010
}

\begin{abstract}
Existence of port that was capture fisheries activity economic centre has very big roles in supporting capture fisheries development in northern coast of Central Java. Still many fishing port mainly fish landing place that the condition and management are very limited if compared to its fisheries progress so needs to expand. Considering the need of high cost investment to develop fishing port/fish landing place in a region, hence it is necessary to compose development priority which become aim of this research through analysis of potential carrying capacity existence. This research was done in survey method to fishing port/fish landing place which extent accross the northern coast of Central Java. This research toke priority analysis and development categorization fishing port/fish landing place using several criterion and indicators of its supporting development that is system and quality of data encode, aspirations from regional and national government, quality of human resources, conditions of road infrastructure to fishing port/fish landing place, condition of transportation facilities from and to fishing port/fish landing place, fishing port/fish landing place facilities and land extent (availibility). It is termination that port priority that will expand are Pekalongan Archipelagic Fishing Port, Coastal Fishing Port Bajomulyo, Coastal Fishing Port Morodemak, Coastal Fishing Port Tawang, and Coastal Fishing Port Asemdoyong. Development of port facilities and activities on the fisheries ought to give attention to sanitation and also its hygienity in order to anticipate the international standard of fishing port.
\end{abstract}

KEYWORDS: $\quad$ potency, fishing port, Central Java

\section{INTRODUCTION}

Capture activity in the waters which has undergone excessive catch, as it was in northern coast of Java Sea, necessited fisherman to fishing in further area as in Natuna Sea, South Waters of Kalimantan and Sulawesi Islands. It is because of the declined of fish resources in the area which used to become fishing ground, hereupon need to be shifted to further area of fishing ground. With this farther fishing ground of fisherman in nothern coast of Java, therefore whole infrastructures and facilities which required to support the activities need to be developed, in other word the size of fishing fleet utilised need to enlarged and so the fishing port scale.

Numbers of fishing port and fish landing place in Northern coast of Java in 2004, each of them represented 71 and $77 \%$ of total 30 fishing port and 210 fish landing place in Java island and most of them about $98 \%$ still those were small scale port or fish landing place.

On the other hand, the existence of fishing port and fish landing place are still lacking in quantity compared to Indonesia coastal length that is 1 fishing port/fish landing place each $7 \mathrm{~km}$ coast (Lubis et al., 2005) and also in quality of its facilities. fishing port and fish landing place extended troughout north region of Central Java Province have quite important positions from the aspect of scattered numbers that represented $34 \%$ of total fishing port/fish landing place in five provinces of North coast of Central Java and most of this fish landing place accomodated small-scale fishing fleet as outboard and motorboat gauged $<30$ GT.

Many fishing port/fish landing place were obstructed in utilization and development caused by the weaknesses of its supporting factor that is road infrastructure, transportation facilities, availibility of accurate production data, human resources, land, and also the lack of government policy including national or local government concerned to fishing port/fish landing place operationality.

Considering the need of high cost investment to develop fishing port/fish landing place in a region, hence it is necessary to compose development priority which become aim of this research through analysis of potential carrying capacity existence.

\section{MATERIALS AND METHODS}

This research was done in 2007 on to fishing port/ fish landing place which extent accross the northern coast of Central Java province. The research toke priority analysis and development categorization

Corresponding author:

Jl. Agatis, Kampus Institut Pertanian Bogor Darmaga, Bogor-16680, E-mail: ernani_ipb@yahoo.com;

beypane_sibolga@yahoo.fr 
fishing port/fish landing place using several criterion and indicators of its supporting development that is system and quality of data encode, aspirations from regional and national government, quality of human resources, conditions of road infrastructure to fishing port/fish landing place, condition of transportation facilities from and to fishing port/fish landing place, fishing port/fish landing place facilities and land extent (availibility).

Data collection was obtained by interviewing and questionaire filling to organizer/manager of fishing port/ fish landing place, fisherman, businessman/trader, manufacturer, secondary data collection from few related instances.

The reason of taking location in Central Java besides caused by great number of fishing port/fish landing place, as explanation previously, is also because this province concentrates $25 \%$ of fisheries fleet number of north coast Java and has market acces or simple distribution from catch yield which landed in fishing port/fish landing place, either local through north coast Java, national and export and easyness on getting information. From 53 sample fishing port/fish landing place taken from Northern coast of Central Java, were selected 13 fishing port/ fish landing place based on criterion fish resources aspects (Directorate General of Fisheries, 2000). Analysis from supporting development will refer to 13 fishing port/fish landing place above they are Pekalongan Archipelagic Fishing Port, Coastal Fishing Port Bajomulyo, Coastal Fishing Port Tegalsari, Coastal Fishing Port Tambak Lorok, Coastal Fishing Port Tanjungsari, Coastal Fishing Port Morodemak, Coastal Fishing Port Wedung, Coastal Fishing Port Banyutowo, Coastal Fishing Port Tasikagung, Coastal Fishing Port Tawang, Coastal Fishing Port Wonokerto, Coastal Fishing Port Asemdoyong, and Coastal Fishing Port Kluwut.

Analysis of planning and development from several fishing port/fish landing place existed in Northern coast of Central Java, worked descriptively by calculating some criterions of supporting capasity of development, as follows:

\section{System and quality of data tabulation (collection)}

System and quality of data tabulation are the most important criterions because valid or invalid (error) result which analysized development objective is started from the accuracy or inaccuracy of the available data. Therefore it needs analysis on data tabulation management and its organizations. In many fishing port/fish landing place the available data oftenly innacurate consequenced by management weakness and quality of human resources who arrange and process data (Lubis et al., 1999). Therefore it is often found result of study development facilities a fishing port/fish landing place in fact it is not suitable to what expected, in capacity or its types.

\section{Aspiration from national and local government}

Existence or non existence development priority from national or local government is indicator which higly needed because from national or local government is stakeholder in the development fishing port/fish landing place. The operational development of fishing port/fish landing place influenced revenue which accepted directly local government as one of its resource of local primary revenue. Furthermore, by operating on this fishing port/fish landing place local primary revenue also obtained indirectly from the emerge of fisheries industry manufactured, industry of material of capture instrument; shopping centre, consultant bureau, and open job demand for local community.

\section{Quality of human resources}

Quality of manager of human resources is as important as criterion of government aspiration which indicated by knowledge level in fishing port/fish landing place developing in order to be optimally functioned. A fishing port/fish landing place which have complete facilities but no good management will make some of its facilities have no or less functioned and finally depraved or maintained. In addition to quality of manager, quality of fishing port/fish landing place subjects as fisherman, trader/middlemen, processor; for example how tc maintain the exist facilities including to keep it clean and to utilize it. It is necessary to held training about the way to utilize facilities, maintain sanitation of facilities and environment surrounding.

\section{Condition of road infrastructure to fishing port/ fish landing place}

Condition of road infrastructure to fishing port/fish landing place is one of criterions which must taken into account in planning of fishing port/fish landing place development. The conditions of road infrastructure is a parameter which determined fluency of fish distribution from fishing port/fish landing place to its hinterland region and conversely from hinterlad 
to fishing port/fish landing place. Condition of road infrastructure comprised regency roads and subdistrict roads.

\section{Conditions of transportations facilities to and from fishing port/fish landing place}

As important as the road infiastructure, condition of transportations facilities to and from fishing port/ fish landing place will impacted the fluency of fish distribution from fishing port/fish landing place to its hinterland region and conversely from hinterlad to fishing port/fish landing place. Fish distribution from fishing port/fish landing place location utilize various transportation facilities which depend on distance taken. Quality of transportation facilities will influence fish quality achieved by consumer. Therefore, type of transportation facilites which used ought to be adjusted with the distance taken.

Method to carry fish must also noted because bad way of fish carrying such carrying use pick up without ice or uncovered above so directly subjected by sun radiation, will quickened decreasing of fish quality.

\section{Facilities of fishing port/fish landing place}

Facility in model/sample of fishing port/fish landing place is one of criterions to program it advance. The facilities are considered from capacity aspect and its utilization, as well as its completeness and its locations system (layout). The facilities utilization which meant is ratio between capacity and its utilization. This will be known until whether facility has passed by the capacity, still fit to capacity or under capacity. As for facility completeness was meant to appraise whether it existences appropriate with the needs or exceed the need (necessity).

Appraisal of facility layout is done to observe whether its existence not supporting, less supporting or supporting efficient and affectivity of fishing port/ fish landing place activities.

\section{Land/area availability}

Fishing port/fish landing place area is the last criterion which same importance with facility criterion, wherein an area of fishing port/fish landing place must be estimated in an analysis of its development planning. It is because the extent (large) and the area status will influence on its planning of facilities expansion.
Several fishing port/fish landing place was found to have a difficulty in its development because of the limited area and if expanded must acquisite the lands which cost quite high.

Furthermore, each fishing port/fish landing place will be scored and weighted on 7 parameters which determined (Apenddix 1). Priority will be acquired with percentage number $>60 \%$ from maximum total value or rate e"26.4.

\section{RESULTS AND DISCUSSION}

\section{Results}

In Central Java Province there are 5 fishing port/ fish landing place achieved priority ready to expand based on development capacity criterions that is based on ranking chronologically Archipelagic Fishing Port Pekalongan, Coastal Fishing Port Bajomulyo, Coastal Fishing Port Morodemak, Coastal Fishing Port Tawang, and Coastal Fishing Port Asemdoyong. First priority achieved by Archipelagic Fishing Port Pekalongan because most of criterions given good value, except the data collection system and method of fish carrying to distribution place gained less good value, In addition, some of its existing facilities have exceeded capacity that is dock and fish auction place. Archipelagic Fishing Port Pekalongan is port which able to accomodate highest fisheries production in Central Java but fish quality organolaptically still less good, therefore need improvement on fish handling in boat or during transportate to its hinterland area.

Coastal Fishing Port Bajomulyo, achieved value (32.33) which not quietly different from Archipelagic Fishing Port Pekalongan that is (34.83), so Coastal Fishing Port Morodemak (31.17). The three of fishing port need to be expanded or developed particularly from the aspects of land availability and existing data collection system. Catch yiels production which landed on these three fish landing place is high categorized if compared to other fish landing place in Central Java. But production capture in Archipelagic Fishing Port Pekalongan showed decreasing or average of its growth (1998-2007) is (-9.4\%) and its production in 2007 left 29.285 ton (Pekalongan Archipelagic Fishing Port, 2008). The layout of its facilities has not supported efficiency and effectivity of its activities yet too. Quality of its human resources still need to be develop and accelerated. 
Table 1. Value/scor achievement based on criterions development aspects fishing port/fish landing place in Central Java

\begin{tabular}{|c|c|c|c|c|c|c|c|c|c|c|}
\hline \multirow{2}{*}{ No. } & \multirow{2}{*}{$\begin{array}{c}\text { Fishing port/fish landing } \\
\text { place name }\end{array}$} & \multirow{2}{*}{ City/Regency } & \multirow{2}{*}{$\begin{array}{l}\mathrm{C} 1 \\
\mathrm{~N} 1\end{array}$} & \multirow{2}{*}{$\begin{array}{l}\mathrm{C} 2 \\
\text { N2 }\end{array}$} & \multirow{2}{*}{$\begin{array}{l}\text { C3 } \\
\text { N3 }\end{array}$} & \multirow{2}{*}{$\begin{array}{l}\mathrm{C} 4 \\
\mathrm{~N} 4\end{array}$} & \multirow{2}{*}{$\begin{array}{l}\text { C5 } \\
\text { N5 }\end{array}$} & \multirow{2}{*}{$\begin{array}{l}\mathrm{C} 6 \\
\mathrm{~N} 6 \\
\end{array}$} & \multirow{2}{*}{$\begin{array}{l}\text { C7 } \\
\text { N7 } \\
\end{array}$} & \multirow{2}{*}{ Average } \\
\hline & & & & & & & & & & \\
\hline 1. & FPN Pekalongan & Pekalongan City & 6 & 6 & 9 & 8 & 6 & 25 & 12 & 34.83 \\
\hline 2. & CFP Bajomulyo & Pati & 6 & 6 & 6 & 8 & 4 & 25 & 12 & 32.33 \\
\hline 3. & CFP Morodemak & Demak & 6 & 6 & 9 & 8 & 2 & 20 & 12 & 31.17 \\
\hline 4. & CFP Tawang & Kendal & 6 & 6 & 6 & 8 & 4 & 20 & 8 & 28.67 \\
\hline 5. & FPP Asem Doyong & Pemalang & 3 & 6 & 6 & 8 & 4 & 20 & 8 & 27.17 \\
\hline 6. & CFP Tasik Agung & Rembang & 3 & 6 & 3 & 8 & 2 & 15 & 12 & 25.00 \\
\hline 7. & FLP Tanjungsari & Pemalang & 0 & 6 & 3 & 8 & 4 & 20 & 8 & 24.17 \\
\hline 8. & CFP Wonokerto & Pekalongan & 3 & 6 & 3 & 4 & 0 & 20 & 12 & 23.67 \\
\hline 9. & FLP Tambak Lorok & Kota Semarang & 6 & 3 & 0 & 4 & 6 & 25 & 8 & 23.33 \\
\hline 10. & FLP Kluwut & Brebes & 3 & 3 & 3 & 8 & 6 & 20 & 4 & 21.67 \\
\hline 11. & CFP Tegalsari & Kota Tegal & 3 & 3 & 3 & 8 & 4 & 20 & 0 & 18.67 \\
\hline 12. & FLP Banyutowo & Pati & 0 & 0 & 0 & 8 & 0 & 20 & 12 & 16.67 \\
\hline 13. & FLP Wedung & Demak & 0 & 0 & 0 & 6 & 0 & 25 & 8 & 15.33 \\
\hline
\end{tabular}

Remarks: c1: data collection system; c2: aspirations of national or local government; c3: quality of human resources; c4: conditions of road infrastructure to fishing port/fish landing place; c5: conditions of transportations facilities to and from fishing port/fish landing place; c6: facilities and activities; c7: land availability; N: value (scor $x$ weight)

Coastal Fishing Port Tawang and Coastal Fishing PortAsemdoyong, both of them are fishing ports which achieved 4 and 5 priority which mean still more of criterions given less or bad value. However, based on result of previously study, priority from national as well as local government, both of the Coastal Fishing Port necessary to be expanded (developed). Table 1 above which is scor achievement based on the determined criterions:

Fishing port activity in fishing port/fish landing place of Central Java generally in progressed. it is indicated with the more growth on urban economy activity and education which supported fisheries development and fisheries porting activity in Central Java. The education activities are existed with Balai Latihan dan Pengembangan Perikanan, Balai Benih Ikan, Sekolah Usaha Perikanan Menengah in Tegal city and, Akademi Perikanan Semarang.

Economy activities are shown by the existence of manufacture of cargo service of ship and plane/water and air cargo service, shipping manufacturer, fisheries exportir manufacturer ( 25 units), ice factory (67 unit). In Archipelagic Fishing Port Pekalongan, activities comprised of fish landing, fish processing and trading trough auction. Fish processing activity which has been grown and located near to fishing port for example is Maya food manufacture worked in fish canning field. Considering the more declined of capture production which were landed in this fishing port (29.285 tons in 2007) therefore it is necessary that fish materials are taken from other fishing port around such as Coastal Fishing Port Bajomulyo and Coastal Fishing Port Wonokerto.

In Coastal Fishing Port Bajomulyo, there are also quite complete activities, only the scale of the job smaller from Archipelagic Fishing Port Pekalongan, however frequency of ship landing not quite different from the one existed in Archipelagic Fishing Port Pekalongan. Processing effort need to be more developed in this fishing port.

Human resources of fisheries sub sector especially in fishing port and fish landing place are one of key succes in Central Java fisheries. If observed from its progress, the progress of human resources of fisheries sub sector in Central Java province generally decline $1.03 \%$ but if it is elaborated, growth of fishermen numbers $(-3 \%)$, extension agents on fisheries field $(+0.2 \%)$, fish seller $(+26.8 \%)$. If it is observed from fishing port/fish landing place management aspect, its quality still need to be accelerated. Fishing port/ fish landing place management meant including management of activities, facilities and its physical environtment. Almost every fishing port/fish landing place in Central Java has limited sanitation conditions. As it was the quality of the subjects in fishing port which got priority to develop, they need counselings which given by the Fisheries Service I or II (Dinas Perikanan Tingkat I dan II) which related to fish handling in boat and in fishing port/fish landing place, during distribution and utilization of existing facilities. 
Just as visible in the field observation, there are basic facilities in the five fishing port/fish landing place necessary to be repaired soon. Almost all of fishing port/fish landing place in Central Java located in the edge or in estuary of river. Therefore silting up factor is common problem in the pool of fishing port as well as in its cruise line. According to the condition, continue dredging is very needed. Other basic facilities which need to be repaired is the dock in Coastal Fishing Port Asem Doyong. As well as functional facilities, some of them need to be repaired such as clean water supply almost in every fishing port in Central Java, floor and building of fish auction place and also KUD and fish processing building.

Supporting facilities such as toilet, waste basket, clean water supply need to add in order to create fishing port/fish landing place area and its environmental cleanliness. Almost all of fishing port/ fish landing place in Central Java, its sanitations and higienity factor have not really been noted by the manager or the subject of fishing port/fish landing place. For example in the area of Coastal Fishing Port Bajomulyo, the parking lot flooded by the former waste water fish and garbage heap. Some of other facilities which need to be expanded are fish auction place for fish auction from fishing boats in Coastal Fishing Port Bajomulyo, and also some facilities in Archipelagic Fishing Port Pekalongan net woned be expanded therefore in its development planning, the Archipelagic Fishing Port Pekalongan location will be expanded accross to Pekalongan river.

\section{Discussion}

Five fishing port/fish landing place which priority recommended to be expanded in northern coast of Central Java region are Archipelagic Fishing Port Pekalongan, Coastal Fishing Port Bajomulyo, Coastal Fishing Port Morodemak, Coastal Fishing Port Tawang, and Coastal Fishing Port Asemdoyong. Geographically, distance between those fishing port/ fish landing place are representative enaough, wherein each priority of fishing port can be centre of growth for other fishing port/fish landing place around it which existed around it.

Coastal Fishing Port Bajomulyo is fishing port type $C$, but its level of service landing almost equal to Archipelagic Fishing Port Pekalongan. Many fishing fleet which has tonage $>30$ GT landing in this Archipelagic Fishing Port. Even in the port area of this region there is a fairly complete facilities.

Coastal Fishing Port Asemdoyong in priorities that will be developed and in the east are Archipelagic
Fishing Port Pekalongan. Therefore, the development of this Coastal Fishing Port Asemdoyong strived to be a buffer for both the fishing port/fish landing place. Even if possible efforts are made to be the best alternative for fish landing and marketing in the region Pemalang.

Archipelagic Fishing Port Pekalongan a fishing port that has the highest service levels in north coast of Central Java. Therefore it is not surprising that in this fishing port many fishing fleet landed and have marketing transaction. Archipelagic Fishing Port Pekalongan position almost exactly in the middle north coast of Central Java allowing fishing port/fish landing place surrounding to grow with uniformly. If Archipelagic Fishing Port Pekalongan developed it is expected that fishing port/fish landing place in the surrounding will also grow. Pekalongan can also be said as the second largest fishing port in terms of fish production after Oceanic Fishing Port Nizam Zachman-Jakarta in the area of north coast of Java. Fishing fleets that came to visit and landing their catch in this port are large fleet tonnage $>30 \mathrm{GT}$. But from the side of the landed fish quality when viewed in organoleptic. Quality of fish in Archipelagic Fishing Port Pekalongan particularly and other fishing port/ fish landing place in Central Java province remains largely low. This will be a barrier if the fishing port internationally or Europe Union standard developed.

In Archipelagic Fishing Port Pekalongan most of the landed catch was poor quality considering the lack of handling on board. Uni Europe states, based on European Union Regulation No.853/2004 about specific hygiene rules for food and animal origin and decisions marine and fisheries minister No.Kep.01/ MEN/2007 about requirements for quality assurance and safety of fishery products that the catchers and transport ships that catch fish to be raw materials of fishery products which will be exported to Uni Europe must meet sanitation requirements and hygiene and must be registered (Directorate of Product Processing and Marketing, 2008). Next Le Ry, 2005 also said that European Union rules since 22 July 1991 about fishing activity, that is hygiene rules for fisherman on board, 2) conditions for preservation of fish on board, 3) conditions for handling on shore, 4) conditions for processing and packing. European Union countries have a quality inspection team before the catch into its hinterland, for example Britain have Environmental Health Office, North East Lincolnshire Council at Immingham fishing port, an institution in Port Entry which task of undertaking the examination of food products into British country in the form of physical documents and product sampling for laboratory analysis. Border inspection in the UK is very strict 
and harsh in its work. If found any contaminant exceeds the standard, the UK policy is fire destroyed the product, not returned or may not processed again. Apparently their motto is if the product is not feasible for them is also not feasible for others. Case that occurred in French, every fishing port has several veterinarians in charge of controlling the quality of fish for local consumption purposes of national and export. Catches are not worthy of consumption will not be allowed to be landed at fishing ports should be transferred directly into fish food factory. Based on the latest developments in European ports such as La Turballe fishing ports, controlling the quality of fish is done automatically by entering fish mucus or blood in the machine and the machine expel labels indicating the quality grade of fish (www. La Turballe). Fishing port of international standard, among others equipped with various facilities that support the operation of fishing activities and fish handling in fishing port, produce good quality fish that can be accepted for export markets, has a clean environment, and hiegienis that supports all activities in the port net fishery also. With the development of fishing port/fish landing place above will increase public welfare and regional development in general.

\section{CONCLUSIONS}

1. There are five fishing ports are priorities to be developed on the northern coast of Java that is Nusantara Fishing Port Pekalongan, Coastal Fishing Port Bajomulyo, Coastal Fishing Port Morodemak, Coastal Fishing Port Tawang, and Coastal Fishing Port Asemdoyong. However, the depth level of interest and the development of the five fishing ports is different. Development needs to be implemented to facilitate the landing and marketing of fish from the fishing fleet in Central Java province.

2. Development of port facilities and activities on the fisheries ought to give attention to sanitation and also its hygienity in order to anticipate the international standard of fishing port.

\section{ACKNOWLEDGEMENTS}

The study was part of the study on fishing port development at the North Coast of Java and its data and information system in 2007 funded by Directorate General of Fisheries. Part of Project SPL-OECF Central of Fishing Port.

\section{REFERENCES}

Directorate General of Fisheries. 2000. Study the Development of Fishing Ports in Pantura Java and Data Systems and Information. Cooperation with PKSPL. IPB.

Directorate of Product Processing and Marketing. 2008. Memorandum of Field Work Reports Dirjen P2HP to England. Ministry of Marine Affairs and Fisheries. Jakarta. 1-3.

Lubis, E., A. B. Pane, \& A. R. Sam. 1999. Fishing port management pattern of efficient and effective in the marine waters of Java and south China sea. Research Reports. RUT. IV. DRN. Jakarta.

Lubis, E., A. B. Pane, Y. Kurniawan, J. Chaussade, C. Lamberts, \& P. Pottier. 2005. Atlas Perikanan Tangkap dan Pelabuhan Perikanan di Pulau Jawa: Suatu Pendekatan Geografi Perikanan Tangkap Indonesia. Bogor. Kerja Sama antara PK2PTMLembaga Penelitian Institut Pertanian Bogor dengan Université de Nantes dan CNRS 6554Nantes. France. 120 pp.

Municipality of Turballe. E-report of Turballe Fishing Port-France. www.La Turballe. 9 Mei 2008: 1-2.

Pekalongan Nusantara Fishing Port. 2008. Annuel Report 2007. Pekalongan. 
Apenddix 1. Criterion and indicator of appraisal in parameter supporting development of fishing port/fish landing place

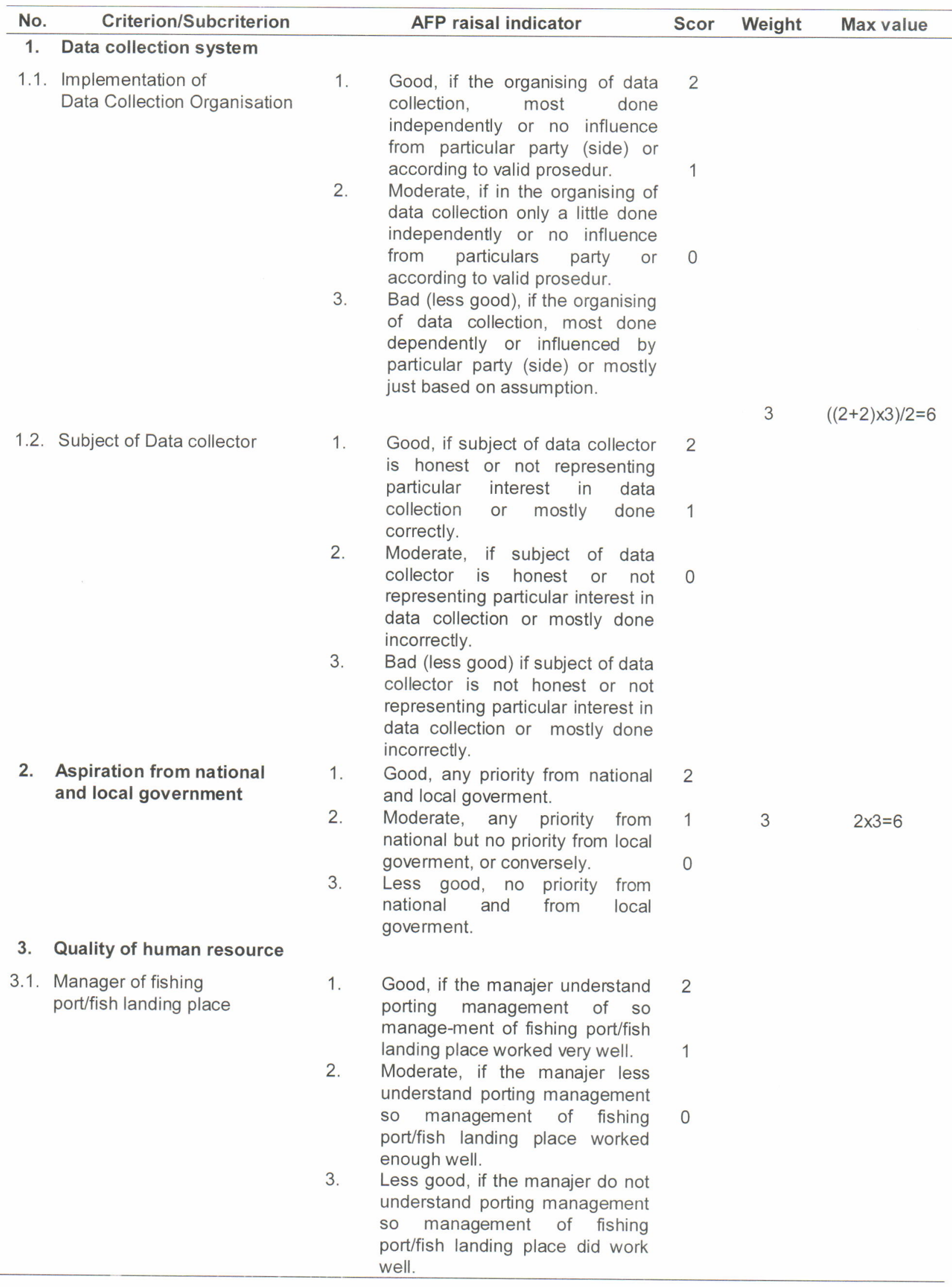



3.2. Subject in fishing 1. Good, if most subjects in FP port/fish landing place have mastered each of their job field.
2. Moderate, if few subjects in FP less mastered each of their job field.
3. Bad (less good), if most subject in FP less mastered each of their job field.

\section{2}

1

3

$((2+2) \times 3) / 2=6$

\section{Conditions of road infrastructure}

4.1. Regency road

4.2. Subdistric road

5. Condition of trans-portation facilities

5.1. Numbers and types of transportation facilities
1. Good, a lot and various.

2. Moderate, a lot and less various.

3. Less, few and no various.
1. Good, all paved (asphalted).

2. Moderate, partly paved (asphalted).

3. Less, all dirt road, or stony. 0

1. Good, all paved (asphalted). 2

2. Moderate, partly paved 1 (asphalted).

3. Less, all dirt road, or stony. 0

\section{$2 \quad((2+2) \times 2) / 2=4$}




\begin{tabular}{|c|c|c|c|}
\hline 6.3. & $\begin{array}{c}\text { Facility layout } \\
\text { system) }\end{array}$ & (location 1. & $\begin{array}{l}\text { Good, exist facilities layout is } \\
\text { supporting efficiency and } \\
\text { effectivity of fishing port/fish } \\
\text { landing place activities. } \\
\text { Moderate, exist facilities layout } \\
\text { is less supporting efficiency and } \\
\text { effectivity of fishing port/fish } \\
\text { landing place activities. } \\
\text { Less good, exist facilities layout } \\
\text { is not supporting efficiency and } \\
\text { effectivity of fishing port/fish } \\
\text { landing place activities. }\end{array}$ \\
\hline
\end{tabular}

\section{Land/area}

7.1. Large (extent) of available land 1. Good, still large if compared to extent of existing building facilities.

2. Moderate, narrow if compared to 1 extent of existing building facilities.

3. Less good, need to expand from 0 the existing area.

7.2. Status of available land

1. Good, property of national/local 2 government.

2. Moderate, property cooperative 1 entreprise.

3. Less good (bad), private 0 property. 
